\title{
AKUISISI SEBAGAI STRATEGI PENGEMBANGAN PERUSAHAAN
}

\author{
Farlianto, MBA Email: Farlianto@yahoo.com \\ Jurusan Manajemen Fakultas EkonomiUniversitas Negeri Yogyakarta
}

\begin{abstract}
ABSTRAK
Pengembangan perusahaan dewasa ini sudah menjadi hal yang rutin dilakukan dalam rangka memaksimalkan kemakmuran stakeholders perusahaan. Berbagai strategi bisa dilakukan dalam rangka mengembangkan perusahaan. Strategi strategi pengembangan perusahaan antara lain adalah melalui akuisisi.

Akusisi memiliki dampak tidak hanya dampak financial namun juga dampak non-financial seperti hubungan antar karyawan yang menjadi kurang harmonis dan lain sebagainya. Dengan melakukan snalisis strategi akuisisi secara mendalam diharapkan tujuan dari perusahaan yaitu untuk memaksimalkan kemakmuran stakeholders perusahan akan dapat diwujudkan.
\end{abstract}

Keywords: Akuisisi, Pengembangan Perusahaan

\section{Pendahuluan}

Perubahan yang terjadi dengan sangat cepat selama tahun-tahun belakangan ini adalah akibat dari serangkaian implementasi kebijaksanaan deregulasi dan debirokratisasi yang mana hal ini telah memberikan dampak yang begitu luas hampir di seluruh sektor perekonomian Indonesia. Dampak yang menonjol antara lain, timbulnya peluangpeluang baru serta makin tajamnya persaingan dalam sektor yang sama dan bahkan antar sektor. Keadaan ini telah menjadi tantangan tersendiri bagi para pengelola bisnis untuk memuaskan pemegang saham atau penanam modal sebagai konsekuensi logis dari bisnis yang sedang tumbuh.

Pada dasarnya perusahaan yang sedang mengalami pertumbuhan dapat memperluas usahanya dengan menggunakan strategi pertumbuhan dengan bergerak melalui tiga tingkatan analisis, yaitu:

\section{Peluang Pertumbuhan Intensif.}

Pada tingkatan ini yaitu dengan mengidentifikasi peluang yang tersedia bagi perusahaan yang dikelolanya yang berada dalam jangkauan operasinya sekarang. Tingkatan analisis ini hanya akan mempunyai arti kalau perusahaan tidak sepenuhnya memanfaatkan peluang dalam produk dan pasarnya sekarang.

\section{Peluang Pertumbuhan Integrasi}

Tingkatan kedua ini yaitu dengan mengidentifikasi peluang untuk berintegrasi dengan lain-lain bagian sistem yang berada dalam industri itu. Pertumbuhan melalui integrasi hanya akan mempunyai arti kalau industri itu kuat dan perusahaan dapat memperolehnya dengan mengadakan integrasi ke belakang, ke depan, atau secara horisontal dalam industri tersebut.

\section{Peluang Pertumbuhan Diversifikasi}

Pada tingkatan ketiga, mengidentifikasi peluang yang terletak diluar industri itu. Pertumbuhan melalui diversifikasi hanya akan berarti kalau pada saat sekarang perusahaan tidak mempunyai banyak kesempatan untuk bertumbuh lebih lanjut atau kalau terdapat kesempatan yang istimewa diluar industri bersangkutan

Dari ketiga tingkatan analisis tersebut, tingkatan analisis yang kedua (pertumbuhan integrasi) dan yang ketiga (pertumbuhan diversifikasi) tidak bisa lepas dari pengambilalihan perusahaan. Pembelian atau pengambilalihan perusahaan-perusahaan tersebut dapat direalisasikan dalam berbagai bentuk. Akuisisi merupakan satu bentuk pengambilalihan tersebut. 
Pembahasan

\section{Akuisisi}

Dalam melakukan suatu pengambilalihan perusahaan, terdapat beberapa hal utama yang harus diperhitungkan akuisitor seperti pemilihan bentuk akusisi yang akan dilakukan dengan melihat karakteristikkarakteristik akuisisi yang ada, pemilihan bentuk dan sumber pembelanjaan akuisisi, penilaian perusahaan target dan juga aspek hukum dari rencana tersebut.

\section{Bentuk-Bentuk Akuisisi}

\subsubsection{Sebagai Salah Satu Bentuk} Kombinasi Bisnis

Akuisisi sebagai salah satu bentuk kombinasi bisnis dapat dibedakan dalam dua tipe yaitu Akuisisi Finansial dan Akuisisi Strategis. Pemilihan antara kedua bentuk akuisisi ini adalah sangat penting karena dapat memberikan gambaran yang jelas tentang latar belakang dan tujuan akuisisi.

\section{Akuisisi Finansial}

Akuisisi finansial merupakan suatu tindakan akuisisi terhadap satu atau beberapa perusahaan tertentu yang dilaksanakan dengan tujuan untuk mencapai keuntungan finansial. Kecenderungannya adalah usaha membeli perusahaan target dengan harga semurah mungkin untuk dijual kembali dengan harga jual yang lebih tinggi. Namun demikian apabila transaksi tersebut dilaksanakan antar perusahaan yang berada dalam satu grup bisnis atau kepemilikan yang sama, harga yang dibeli dapat menjadi lebih mahal atau pun lebih murah, tergantung pada kepentingan dan keuntungan yang akan diperoleh pemilik mayoritas bersangkutan. Motif utama akuisisi ini adalah untuk mengeruk keuntungan finansial sebesar-besarnya.

\section{Akuisisi Strategis}

Akuisisi strategis merupakan suatu akuisisi yang dilaksanakan dengan tujuan untuk menciptakan sinergi dengan didasarkan pada pertimbanganpertimbangan jangka panjang. Sinergi ini tidak hanya berupa sinergi finansial tetapi juga mencakup sinergi produksi, sinergi distribusi, sinergi pengembangan teknologi dan gabungan dari sinergisinergi tersebut. Dalam rangka mewujudkan sinergi tersebut maka perusahaan pertama mengakuisisi perusahaan kedua sehingga dapat menutup kelemahan-kelemahan mereka yang sekaligus meningkatkan penjualan dan menampilkan kekuatan yang lebih besar. Sinergi ini mencerminkan penggabungan dua faktor yang akan menghasilkan keuntungan yang lebih besar dibandingkan dengan jumlah keuntungan yang dihasilkan apabila masing-masing faktor tersebut bekerja sendiri-sendiri

\subsubsection{Kaitan Dengan Aspek}

Pemasaran

Apabila dikaitkan dengan aspek pemasaran maka terdapat tiga bentuk akuisisi yang perlu dipertimbangkan, yaitu :

1. Akuisisi dalam Bentuk Integrasi Horisontal

Akuisisi dalam bentuk integrasi horisontal ditujukan untuk mengakuisisi pesaing langsung. Pesaing yang dimaksud adalah dapat berupa pesaing yang memiliki produk dan jasa yang sama ataupun pesaing yang memiliki daerah pemasaran yang sama. Tindakan akuisisi ini biasanya bertujuan untuk perluasan pasar.

2. Akuisisi dalam Bentuk Integrasi Vertikal

Akuisisi dalam bentuk vertikal ditujukan untuk menguasai sejumlah mata rantai produksi dan distribusi dari hulu sampai ke hilir.

3. Akuisisi dalam Bentuk

\section{Diversifikasi}

Akuisisi dalam bentuk diversifikasi ditujukan untuk mengakuisisi perusahaan lain baik yang mempunyai kaitan bisnis dengan perusahaan maupun yang tidak mempunyai kaitan bisnis dengan perusahaan akuisitor.

1.2.3. Segi Aplikasi Penjabaran Akuisisi 
Bila ditinjau dari segi aplikasi penjabaran akuisisi terhadap suatu perusahaan maka akuisisi dapat berbentuk, yaitu :

1. Asset Acquisition

Asset acquisition merupakan suatu transaksi pembelian perusahaan untuk mendapatkan sebagian atau seluruh aktiva perusahaan target. Pengalihan aktiva tersebut direalisasikan melalui instrumen khusus untuk tiap aktiva perusahaan. Dalam hal kewajiban (liabilities) tidak secara otomatis dialihkan kepada pembeli. Pembeli dapat mengambil alih kewajiban tersebut bilamana telah ada persetujuan sebelumnya dalam kontrak akuisisi.

\section{Stock Acquisition}

Stock acquisition merupakan suatu transaksi pembelian sebagian atau seluruh saham perusahaan target. Apabila penjual hanya dimiliki oleh segelintir orang dan bukan merupakan perusahaan publik maka proses akuisisi saham ini adalah yang mudah. Sebaliknya apabila perusahaan target merupakan perusahaan publik yang sahamnya dimiliki oleh banyak orang maka proses akuisisinya bukanlah merupakan hal yang mudah dan membutuhkan waktu yang relatif lama. Penjualan saham ini lebih sering terjadi dibandingkan dengan penjualan aktiva yang mana hal ini seringkali lebih dikarenakan penjual tersebut masih terikat pada kontrak-kontrak tertentu seperti leases, franchises atau perijinan lainnya yang tidak dapat dialihkan kepada pembeli.

3. Statutory Mergers
Statutory mergers merupakan kombinasi antara dua perusahaan atau lebih sesuai dengan ketentuan yang disyaratkan dalam undang-undang. Konsekuensi dari merger ini adalah salah satu perusahaan secara hukum masih tetap berdiri sedangkan perusahaan lainnya harus dilikuidasi. Perusahaan yang dipertahankan tersebut tidak hanya mewarisi aktiva dan kewajibannya tetapi juga mewarisi aktiva dan kewajiban perusahaan yang dilikuidasi. Kemungkinan lainnya adalah dipertahankannya perusahaan penjual sedangkan perusahaan pembeli yang dilikuidasi. Hal ini terjadi apabila penjual memiliki aktiva yang lebih berharga dan tidak dapat dialihkan karena pertimbangan akan faktor legal dan faktor-faktor lainnya. Penggabungan tersebut sering disebut "reverse merger".

4. Statutory Consolidation

Statutory consolidation juga merupakan kombinasi dua perusahaan atau lebih yang tunduk pada peraturan dan perundang-undangan yang berlaku dan membutuhkan persetujuan terlebih dahulu dari stockholders dan board of directors. Namun demikian konsolidasi ini adalah berbeda dengan pengertian merger karena dalam konsolidasi tersebut akan timbul suatu perusahaan baru akibat dari adanya kombinasi tersebut. Perusahaan baru ini mewarisi seluruh aktiva dan kewajiban-kewajiban perusahaan yang terlibat didalam kombinasi tersebut.

\section{Karakteristik Transaksi Akuisisi}

Fenomena akuisisi merupakan suatu fenomena yang sangat kompleks karena tidak hanya melibatkan para pelaku akuisisi tetapi juga melibatkan pihak lain seperti lembaga keuangan, lembaga perpajakan dan pemegang saham publik. Salah satu wujud dari kompleksitas masalah akuisisi adalah kompleksnya transaksi akuisisi. Suatu jenis transaksi akuisisi tertentu mempunyai karakteristik yang berbeda dengan karakteristik akuisisi lainnya.

2.3.1. Transaksi Akuisisi atas Dasar Kas

Transaksi akuisisi atas dasar kasi ini ditandai dengan pengeluaran sejumlah kas oleh pihak akuisitor untuk membayar saham perusahaan target. Sumber dana yang digunakan untuk melunasi transaksi akuisisi ini dapat bersumber dari surplus kas yang dimiliki akuisitor, penjualan harta milik akuisitor, penjualan saham milik akuisitor maupun melalui penerbitan obligasi. Seringkali sumber pembiayaan untuk transaksi kas ini berasal dari sumber eksternal seperti 
pinjaman bank maupun kombinasi antara sumber-sumber pembiayaan eksternal dan sumber-sumber pembiayaan internal.

\subsubsection{Transaksi Akuisisi atas} Dasar Saham

Transaksi Akuisisi atas dasar saham ditandai dengan penyerahan sebagian saham milik akuisitor sebesar saham perusahaan target yang dibelinya. Pada umumnya saham yang diserahkan tersebut merupakan saham akuisitor. Namun demikian dapat saja terjadi saham yang diserahkan tersebut bukan merupakan saham milik akuisitor melainkan saham perusahaan anak milik akuisitor ataupun saham perusahaan lain yang dibeli akuisitor dari bursa saham.

Seringkali latar belakang dilaksanakannya suatu transaksi akuisisi atas dasar saham adalah dimaksudkan untuk menciptakan dan meningkatkan kerjasama dibidang tertentu. Bahkan kerjasama ini cenderung dapat menciptakan suatu bentuk aliansi strategis (strategic alliance). Manfaat yang diharapkan dari kerjasama ini adalah mengeliminasi dampak negatif berupa persaingan bisnis diantara perusahaan target dan akuisitor bilamana keduanya mempunyai jalur bisnis yang sama atau berkaitan erat satu sama lainnya. Usaha penghindaran diri dari persaingan mempunyai dampak yang sangat besar bagi perkembangan dan kelangsungan usaha karena membawa konsekuensi terhadap pengurangan persaingan harga dan pemborosan sumber daya perusahaan.

\subsubsection{Transaksi Akuisisi atas}

Dasar Aktiva

Transaksi akuisisi atas dasar aktiva ditandai dengan penyerahan aktiva atau harta milik akuisitor kepada perusahaan target untuk melunasi saham yang dibelinya. Aktiva yang diserahkan tidak harus milik akuisitor melainkan dapat berupa aktiva yang dimiliki pihak lain yang dibeli oleh akuisitor untuk diserahkan kepada perusahaan target.

\subsubsection{Transaksi}

Akuisisi Kombinasi

Transaksi akuisisi dengan cara kombinasi ditandai dengan kombinasi antara transaksi kas, transaksi saham dan transaksi aktiva perusahaan. Karakteristik transaksi akuisisi ini dimungkinkan karena adanya tuntutan fleksibilitas dalam proses pelaksanaan transaksi akuisisi. Hal ini karena seringkali suatu transaksi akuisisi membutuhkan sejumlah uang yang relatif besar sehingga dibutuhkan banyak sumber dana untuk melunasi transaksi akuisisi tersebut.

\subsubsection{Transaksi}

Akuisisi

Bertahap Ganda

Dalam transaksi akuisisi bertahap ganda, penyelesaian transaksi akuisisinya secara bertahap dalam periode yang relatif panjang. Pada tahap awal pihak akuisitor hanya menyalurkan sebagian dana kepada perusahaan target. Setelah itu sesuai dengan perjanjian yang telah disepakati oleh kedua belah pihak, apabila perusahaan target berhasil meningkatkan kinerja usahanya maka pihak akuisitor berhak membeli dan menambah sejumlah dana lagi. Penyetoran tambahan dana segar ini terrus berlangsung hingga mencapai jumlah optimal saham yang dibeli sesuai dengan kesepakatan yang telah dibuat sebelumnya.

2.3.6. Transaksi Akuisisi Dengan Cara LBO (Leverage Buy-Out)

Leverage Buy-Out merupakan cara menciptakan keuntungan melalui cara pengambilalihan seluruh saham (buy-out) perusahaan target yang dilunasi dengan surplus cash flow ataupun dengan cara mengumpulkan dana dari hasil penjualan aktiva yang seringkali bersumber dari perusahaan target. Misalkan pengambilalihan kepemilikan suatu perusahaan property yang bergerak dibidang persewaan gedung perkantoran. Pelunasan transaksi akuisisi ini dilakukan secara bertahap dengan cara menggunakan dana yang bersumber dari hasil pendapatan penyewaan gedung kantor bersangkutan. Dengan demikian 
dalam pengambilalihan perusahaan target, akuisitor hanya mengeluarkan sejumlah dana yang relatif kecil untuk kelancaran proses awal pengambilalihan perusahaan terget tersebut. Bagi akuisitor (investor LBO), penentuan suatu transaksi yang menarik secara finansial mempertimbangkan tiga faktor berikut, yaitu :

1. Ukuran dan stabilitas peramalan arus kas operasi (operating cash flow forecast).

2. Jumlah investasi modal yang dikehendaki.

3. Biaya bunga dan deviden yang dikaitkan dengan tipe pembelanjaan (financing) yang digunakan.

Pembelanjaan Akuisisi

Masalah pembelanjaan akuisisi meliputi masalah pemilihan tipe alat pembelanjaan, sumber-sumber pembelanjaan, pemilihan alternatif pembelanjaan.

\subsubsection{Bentuk-Bentuk}

Pembelanjaan Akuisisi

Dalam pengertian luas, currenties keuangan untuk suatu akuisisi meliputi :

\section{$1 . \quad$ Debt}

Diasumsikan bahwa sebuah perusahaan pembeli lebih berkeinginan untuk menggunakan sumber keuangan dari luar perusahaan daripada menggunakan modal intern yang dimiliki. Pembelanjaan dalam bentuk debt ini telah digunakan secara luas dan bervariasi oleh berbagai perusahaan.

\section{Equity}

Equity merupakan salah satu tawaran alternatif bentuk pembelanjaan yang cukup menarik untuk periode mendatang. Investor mengharapkan untuk mendapatkan suatu hasil berupa apresiasi jangka panjang dari investasinya, lebih besar daripada pembayaran bunga untuk periode sekarang.

3. Hybrid Securities

Salah satu metode yang digunakan dalam rangka mencapai rate of return yang lebih tinggi dengan cara menciptakan keserasian antara debt dan equity disebut sebagai Hybrid Securities. Keserasian tersebut adalah berupa hak opsi untuk membeli sejumlah saham tertentu pada tingkat harga tertentu yang telah ditentukan sebelumnya. Salah astu alternatifnya adalah debt dikonversikan menjadi saham biasa beberapa saat sebelum tanggal jatuh tempo.

4. Contingent Payments

Dalam negosiasi seringkali timbul perbedaan opini antara pembeli dan penjual mengenai nilai perusahaan yang tidak dapat direkonsialisasi. Hal ini sebagai akibat perbedaan persepsi mengenai potensi perolehan laba perusahaan di masa datang. Alternatif bentuk pembelanjaan berikutnya yang berhubungan dengan latar belakang tersebut di atas, adalah contingent payment. Bentuk pembelanjaan ini adalah berkaitan erat dengan bentuk pembelanjaan atas selisih yang timbul antara harga yang ditentukan penjual (seller's price) dan harga yang ditentukan pembeli (buyer's price) pada saat perusahaan mendapatkan hasil operasi yang lebih tinggi. Contingent payments ini seringkali disebut "earnouts".

\section{Cash}

Pembeli pertama-tama cenderung mempertimbangkan untuk menggunakan dana kas atau sumber modal lainnya yang telah tersedia dalam perusahaan daripada mencari sumber pembelanjaan akuisisi dari luar perusahaan. Keputusan untuk menggunakan sumber pembelanjaan dari dalam perusahaan bersangkutan adalah lebih mengarah pada pertimbangan akan faktor pajak terutama berupa pengenaan pajak atas deviden maupun pengenaan pajak penghasilan. Sehingga ditempuh salah satu alternatif pembelanjaan akuisisi yakni dengan cara mengumpulkan uang kas yang dimiliki perusahaan untuk diinvestasikan kembali dalam suatu akuisisi. Selain dilatarbelakangi pertimbangan akan pajak terdapat alasan lain yang seringkali merupakan alasan dipilihnya kas sebagai sumber pembelanjaan akuisisi. Alasan tersebut adalah keterbatasan kemampuan 
perusahaan untuk mendapat sumber dana dari luar perusahaan.

6. Bentuk-bentuk

Pembelanjaan Lainnya.

Beberapa bentuk pembelanjaan lainnya seringkali melibatkan pihak ketiga dalam kaitannya dengan negosiasi antara pembeli dan penjual. Tipe pembelanjaan ini bukanlah merupakan tipe pembelanjaan tradisional. Tipe pembelanjaan ini antara lain meliputi :

\section{a. Sale-Leasebacks}

Cara pembelanjaan yang dianggap lebih mudah dilakukan yakni dengan cara menjual sejumlah aktiva perusahaan kepada suatu lembaga keuangan dan setelah itu disewa kembali oleh perusahaan bersangkutan. Aktiva tersebut dapat berupa gedung, mesin, kendaraan dan peralatan pabrik. Cara ini disebut sale-leaseback.

b. Assets Retained by The Seller

Sebagian akuisisi dilaksanakan sebagai pembelian atas saham yang dimiliki suatu perusahaan namun sebagian akuisisi lainnya dilaksanakan sebagai pembelian atas aktiva dan kewajiban suatu perusahaan. Apabila suatu transaksi dilaksanakan sebagai suatu pembelian aktiva maka penjual dapat menyetujui untuk menahan aktiva tertentu yang tidak berpengaruh penting terhadap kegiatan bisnis ataupu dapat menukar dan mengurangi nilai suatu aktiva yang ditahannya tersebut.

c.Asset leased from the seller.

Penjual juga dapat menyetujui untuk menahan aktiva tertentu

\section{d. Service Contract}

Dalam situasi tertentu penjual dapat menyetujui memberikan jasa (service) yang berkelanjutan kepada pembeli dengan membebankan sejumlah fee. Dengan demikian pembeli dapat mengurangi harga yang ditawarkan tergantung pada jumlah fee.

e. Employment Contract

Penjual dapat menyetujui untuk mengurangi harga yang ditawarkannya yang pada esensinya merupakan porsi pembelanjaan atas harga sebagai kompensasi dari suatu persetujuan mengenai tenaga kerja. Peluang untuk negosiasi mengenau kontrak tenaga kerja yang berkelanjutan dapat timbul apabila penjual merencanakan untuk tetap aktif dalam bisnis tersebut.

f. Non Competition Agreement

Pihak penjual yang memiliki suatu pengetahuan yang bernilai dapat menyetujui untuk menerima suatu porsi harga beli tertentu dan menganggap pembayarannya sebagai suatu kompensasi atas persetujuan untuk tidak bersaing.

\subsubsection{Sumber-Sumber}

Pembelanjaan Akuisisi

Dalam beberapa tahun belakangan ini pasar uang uang telah berkembang cukup siknifikan. Sumber pembiayaan untuk suatu akuisisi menjadi lebih beraneka ragam, yaitu:

\section{Private Placement}

Pemeran utamanya adalah commercial banks, perusahaan asuransi, dana pensiun dan modal ventura. Kemampuan suatu lembaga tertentu untuk turut berpartisipasi dalam sebagian atau seluruh private placement tersebut pada prinsipnya tergantung pada masalah peraturan dan hukum yang berlaku.

\section{Public Markets}

Pelaksanaan go public melalui pasar modal merupakan salah satu alternatif yang cukup layak.

\section{$3 . \quad$ Sellers}

Pembelanjaan penjual selalu diterapkan karena penjual seringkali memperoleh keuntungan melalui partisipasi tersebut.

4. Buyers
Kesempatan pembeli untuk mendapatkan dana lewat suatu penawaran saham atau penerbitan obligasi yang sesuai dengan perjanjian dan pada suatu saat yang ditentukan, obligasi tersebut dikonversikan menjadi equity (convertible bonds).

\section{Penilaian dan Penetapan Harga Akuisisi}

2.5.1. Latar Belakang Pembuatan Analisis Penilaian 
Kegagalan negosiasi suatu akuisisi seringkali disebabkan oleh masalah harga, terutama bagi penjual dalam hal untuk memutuskan menjual pada tingkat harga tertentu. Dengan menggunakan analisis penilaian, penjual dapat memperoleh manfaat berikut ini, yaitu :

a. Penentuan suatu tingkat harga yang didasarkan pada kondisi pasar saat dijual.

b. Terjamin bahwa harga yang ditawarkan bukan merupakan harga yang rendah (underprice).

c.Dapat menetapkan ekspektasi harga yang layak dan membuat konsesnsus di antara pemilik perusahaan.

d. Memberikan umpan balik bagi alternatif pengambilan keputusan untuk menjual, menahan, go public ataupun melakukan likuidasi perusahaan.

e. Memperkuat negosiasi penjualan dengan menggunakan informasi yang diperoleh selama analisis penilaian tersebut.

Sedangkan bagi pembeli, analisis penilaian dapat membantu dalam beberapa hal, yaitu :

a. Penentuan suatu tingkat harga yang didasarkan pada kondisi pasar saat dibeli.

b. Terjamin bahwa harga yang ditawarkan adalah bukan merupakan harga yang tertinggi atau mahal (overprice).

c.Mempertimbangkan pengaruh berbagai alternatif skenario pertumbuhan yang dianggap menarik.

d. Memperkuat negosiasi pembelian dengan menggunakan informasi yang diperoleh melalui analisis penilaian.

e. Melengkapi pemahaman tentang industri dan posisi persaingan.

\subsubsection{Metode}

Penilaian

Perusahaan

Suatu perusahaan dapat dinilai dengan menggunakan tiga pendekatan berikut ini :

1. Pasar (market).

Dalam pendekatan pasar ini, faktor harga digunakan sebagai dasar penilaian.
Metode yang digunakan yaitu metode perbandingan pasar (market comparisson methods). Fokus utamanya adalah pada transaksi yang terjadi di pasaran. Market comparison methods didasarkan pada asumsi nilai suatu perusahaan dapat diestimasi melalui analisis terhadap harga yang dibayarkan untuk pemilik minoritas atau seluruh pemilik yang berkepentingan terhadap perusahaan bersangkutan. Harga yang dibayarkan kepada pemilik perusahaan dapat diketahui dari 3 jenis pasar yang menghasilkan harga-harga berikut ini :

a) Harga yang dibayarkan untuk saham yang diperdagangkan kepada publik yakni harga yang dibayarkan oleh investor di secondary market untuk kepentingan kepemilikan yang relatif sangat kecil.

b) Harga yang dilaporkan dalam suatu akuisis yakni harga yang dibayarkan oleh pembeli yang berkepentingan terhadap kepemilikan dalam akuisisi yang dilaporkan tersebut.

c) Harga yang dibayarkan dalam initial public offerings (IPOs) yakni harga yang dibayarkan oleh investor untuk kepentingan kepemilikan yang relatif sangt kecil dalam suatu perusahaan ketika sahamnya untuk pertama kali ditawarkan kepada publik.

Tahapan-tahapan dalam penerapan market comparison methods adalah sebagai berikut :

a) Menetapakan market price multiples (MPM)

MPM diperoleh dengan cara membagi harga pasar saham dengan faktor-faktor yang memberikan kontribusi terhadap harga pasar saham tersebut. Faktor-faktor tersebut misalnya laba perusahaan, arus kas, dan nilai buku. Tujuannya adalah untuk mendapatkan rumus perhitungan harga pasar, misalnya membandingkan antara harga dan laba, harga dan arus kas, serta harga dan nilai buku.

b) Menerapkan harga multiple tersebut pada data keuangan. Penerapan tersebut akan menghasilkan harga pasar yang berbeda, karena 
perbedaan ketiga perbandingan atau ketiga multiple tersebut.

nilai keseluruhan dengan cara menghitung atribut rata-rata pada masing-masing estimasi nilai tersebut. Nilai rata-rata tersebut dipengaruhi oleh nilai yang diberikan pada karakteristik prestasi perusahaan dan konsistensi multiple yang dibawa oleh perusahaan yang bersangkutan.

d) Terakhir adalah penerapan discount dan atau premiums yang merupakan refleksi pada perbedaan penilaian pada pemilikan $100 \%$ (atau paling kurang sebagai mayoritas) dan pemilikan minoritas.

2. Pendapatan (income).

Sedangkan dalam pendekatan pendapatan, faktor proyeksi laba dan surplus cash flows digunakan sebagai dasar penilaian. Pada umumnya metode yang digunakan adalah metode discounted cash flow (DCF). Fokus utamanya adalah pada financial performance di masa mendatang. Metode ini menggunakan asumsi bahwa nilai perusahaan pribadi atau perusahaan publik dapat diestimasi pada saat itu melalui proyeksi financial performance di masa datang dan identifikasi surplus cash flows yang dihasilkan perusahaan. Setelah mengetahui surplus cash flows untuk beberapa tahun kemudian, lalu diperhitungkan discounted dengan memperhitungkan kembali resiko cost of capital yang dihadapi sekarang, untuk mendapatkan net present value (NPV) untuk cash flows di masa datang. NPV dijabarkan sebagai nilai pasar perusahaan. Dengan demikian DCF ini secara tidak langsung menunjukan bahwa cash flows yang lebih besar akan memberikan nilai yang lebih besar bagi perusahaan. Untuk menerapkan metode DCF, perlu pemahaman yang lebih jelas mengenai bisnis dan prestasi di masa lalu dan prospek pertumbuhan di masa yang akan datang. Adapun tahapan-tahapan penerapan metode DCF adalah sebagai berikut : a) Mengembangkan suatua proyeksi financial performance untuk 5 tahun atau lebih.

b) Mengidentifikasi surplus cash flows.

c) Membuat estimasi nilai perusahaan pada akhir peiode forecast.

d) Membuat estimasi tentang beban cost of capital.

e) Menghitung nilai akhir periode proyeksi yang mencakup cash flows dan cost of capital.

f)Mengurangi pinjaman perusahaan, untuk membuat estimasi niali bisnis terhadap pemiliknya.

3. Biaya (cost).

Terakhir adalah pendekatan biaya yang fokusnya pada aktiva, baik aktiva berwujud (tangible assets) maupun aktiva tidak berwujud (intangible assest). Pendekatan ini didasarkan pada aktiva perusahaan dan kewajiban perusahaan. Metode yang dipakai ialah Restated Balance Sheet Method (RBS). Metode ini juga disebut sebagai metode net assets value atau adjusted stock value. Menurut metode RBS, nilai suatu bisnis operasi tertentu tergantung pada total aktiva dikurangi dengan kewajibannya, di mana tiap aktiva dan kewajiban perusahaan tersebut dinilai berdasarkan nilai pasar yang wajar. Asumsinya adalah jumlah aktiva dinilai kembali dengan harga pasar yang wajar dikurangi dengan total kewajiban yang dinilai kembali dengan harga pasar yang wajar.

2.6. Announcement Dates of Acquisition

Setelah semua tahapan diatas dilalui yaitu pemilihan bentuk akusisi yang akan dilakukan dengan melihat karakteristik-karakteristik akuisisi yang ada, pemilihan bentuk dan sumber pembelanjaan akuisisi, penilaian perusahaan target dan juga aspek hukum dari rencana tersebut dipenuhi, event berikutnya adalah mengumumkan rencana akuisisi tersebut. Bagi perusahaan yang sudah go public, pengumuman rencana akuisisi tersebut disamping 
dilaporkan kepada Bapepam juga harus diumumkan kepada publik sebagai informasi yang dapat dijadikan salah satu pilihan investasi yang akan dilakukan oleh publik investor melalui pasar modal dengan pembelian suatu saham. Setelah pengumuman, dalam waktu yang tidak terlalu lama kemudian dilanjutkan dengan transaksi bilamana semua telah terdapat kesepakatan.

\section{Kesimpulan}

Penggunaan strategi akuisisi dalam mengembangkan perusahaan haruslah dilakukan secara cermat dan terencana. Hal ini karena tujuan dari perusahaan adalah dalam rangka memaksimalkan kemakmuran stakeholders perusahaan. Memaksimalkan kemakmuran stakeholders hendaknya benar-benar menjadi landasan pertimbangan dalam pengembangan perusahaan, dimana dengan melakukan analisa secara seksama rencana akuisisi yang akan dilakukan akan menghasilkan nilai perusahaan yang lebih optimal.

\section{DAFTAR PUSTAKA}

Brigham, Eugene F., 1992, Fundamentals of Financial Management, 6th Edition, The Dryden Press, New York.

Elton, Edwin J., and Gruber, Martin J., Modern Portofolio Theory and Investment Analysis, 4th Edition, John Wiley and Sons.

Go, Marcel, 1992, Akusisi Bisnis : Analisis dan Pengelolaan, PT Rineka Cipta, Jakarta.

Healy, Paul M., Palepu, Krishna G., and Ruback, Richard S., 1992, "Does Corporate Performance Improve after Merger?", Journal of Financial Economics 31, $135-175$.

Kotler, P. and Armstrong, G., 1991, Principles of Marketing, 5th Edition, Prentice-Hall International, Inc.

Lewellen, W., Loderer, C., and Rosenfeld, A., 1989, "Merger, Executive Risk Reduction, and Stockholder Wealth", Journal of Financial and Quantitative Analysis 24, 4, December, 459 - 472.

Sartono, Agus, 1995, Manajemen Keuangan : Teori dan Aplikasi, Edisi 2, BPFE - Yogyakarta. 